\title{
OBOWIAZZKI PAŃSTWA W KONTEKŚCIE ZATRUDNIANIA OSÓB NIEPEŁNOSPRAWNYCH - KILKA REFLEKSJI NA TLE WYBRANYCH REGULACJI KONSTYTUCYJNYCH
}

\author{
Abstract \\ State duties in the context of disability related employment law - some remarks \\ on chosen constitutional regulations
}

Eliminating discrimination in respect of employment law is solely one of numerous elements of prohibiting and avoiding discrimination for disabled persons in their every-day life. However, it is remarkably exposed in employment and labour law, considering that discrimination in such area might lead to a particular distress. For these reason a state must undertake the measures not only in the context of the inferior position of disabled employees, but first of all in the context of their rights as humans who have to earn their living being employed. Considering this, the paper aims at listing the state duties related to an employment policy as well as to a social security policy, an education or training and a social communication.

Słowa kluczowe: zatrudnienie, pracownik niepełnosprawny, dyskryminacja, konstytucja

Key words: employment, disabled employee, discrimination, constitution

\section{Zagadnienia wstępne}

Zgodnie $\mathrm{z}$ art. 32 Konstytucji $\mathrm{RP}^{1}$ : Wszyscy są wobec prawa równi. Wszyscy mają prawo do równego traktowania przez władze publiczne. Nikt nie może być dyskryminowany w życiu politycznym, społecznym lub gospodarczym z jakiejkolwiek przyczyny. Konsekwencją decyzji ustrojodawcy jest to, że - jak trafnie zauważono w doktrynie - dla oceny konstytucyjnej dopuszczalności różnicowania sytuacji podmiotów podobnych znaczenie zasadnicze ma pytanie, czy jest to różnicowanie uzasadnione, a nie pytanie na podstawie jakich cech zostało dokonane. Każde bowiem zróżnicowanie sytuacji podmiotów podobnych, które nie znajduje uzasadnienia, trzeba uznać za dyskryminację

\footnotetext{
${ }^{1}$ Konstytucja Rzeczypospolitej Polskiej z dnia 2 kwietnia 1997 r. (Dz. U., Nr 78, poz. 483).
} 
$\mathrm{w}$ rozumieniu art. 32 ust. 2 , a więc za naruszenie konstytucji². Podobny punkt widzenia prezentuje Trybunał Konstytucyjny, kiedy stwierdza, że zasada równości wobec prawa i równości w prawie jest zachowana, jeżeli wszystkie podmioty charakteryzujące się daną cechą (relewantną) są traktowane tak samo, według jednakowej miary33.

Nie ulega wątpliwości, że zakaz dyskryminacji i wyrównywanie szans to dwa kluczowe pojęcia w zakresie realizacji praw osób niepełnosprawnych. W demokratycznym państwie prawnym urzeczywistniającym zasady sprawiedliwości społecznej nie może być mowy o akceptacji sytuacji, gdy osoba niepełnosprawna na skutek dysfunkcji swojego organizmu nie ma zagwarantowanych tych samych praw, co osoba pełnosprawna. Żeby urzeczywistnić zasady równości i sprawiedliwości społecznej, osoby te należy objąć dodatkowymi przywilejami i szczególną pomocą władz publicznych. Trzeba pamiętać, że przyznanie specjalnych uprawnień nie oznacza dyskryminacji pozostałych, pełnosprawnych obywateli. Przywileje te nie zmierzają bowiem do faworyzowania określonych kategorii osób, lecz chodzi w nich wyłącznie o wyrównywanie szans. Tylko dzięki takim udogodnieniom grupy zagrożone społeczną alienacją będą mogły funkcjonować w społeczeństwie na równych zasadach. Niepełnosprawność nadal niestety wywołuje niechęć, a czasami nawet wrogość, a przez to utrudnia funkcjonowanie osobom niepełnosprawnym w życiu codziennym. Biorąc to pod uwagę, wydaje się, że zasada równości wobec prawa pozostaje w ścisłym związku z zasadą sprawiedliwości społecznej ${ }^{4}$. Jak słusznie bowiem zauważył T. Zieliński, „sprawiedliwość społeczna jest wręcz utożsamiana z równością szans w zaspokajaniu potrzeb życiowych, bez zróżnicowań zarówno dyskryminujących, jak też faworyzujących ludzi znajdujących się w takich samych sytuacjach"5.

Z punktu widzenia tytułowej problematyki zakaz dyskryminacji jest jedną z instytucji mającą zapewnić równą pozycję pracowników w stosunkach pracy. Zakaz ten został ustanowiony, aby chronić osoby szczególnie narażone na wykluczenie lub traktowanie mniej korzystne niż większość zatrudnionych ${ }^{6}$. Trzeba jednak pamiętać, że samo

${ }^{2}$ L. Garlicki, Artykuł 32, w: K. Działocha, L. Garlicki, P. Sarnecki, W. Sokolewicz, J. Trzciński, Konstytucja Rzeczypospolitej Polskiej. Komentarz, t. 3, Warszawa 2003, s. 21.

${ }_{3}^{3}$ Zob. orzeczenie TK z dnia 9 marca 1987 r., sygn. U 7/87, OTK 1988, cz. 1, poz. 1. Formuła ta znajduje potwierdzenie w dalszych orzeczeniach TK. Zob. orzeczenia TK z dnia: 6 maja 1998 r., K 37/97, OTK 1998, Nr 3, poz. 33; 20 października 1998 r., K 7/98, OTK 1998, Nr 6, poz. 96 ; 17 maja 1999 r., P 6/98, OTK 1999, Nr 4, poz. 76; 21 września 1999 r., K 6/98, OTK 1999, Nr 6, poz. 117; 4 stycznia 2000 r., K 18/99, OTK 2000, Nr 1, poz. 1; 18 grudnia 2000 r., K 10/00, OTK 2000, Nr 8, poz. 298; 21 maja 2002 r., K 30/01, OTK-A 2002, Nr 3, poz. 32; 22 lutego 2005 r., K 10/04, OTK-A 2005, Nr 2, poz. 17; 18 grudnia 2008 r., K 19/07, OTK-A 2008, Nr 10, poz. 182.

${ }_{4}^{4}$ E. Olejniczak-Szałowska, Zasada legalności, zasada równości wobec prawa i zasada sprawiedliwości społecznej, w: Z. Duniewska, B. Jaworska-Dębska, R. Michalska-Badziak, E. Olejniczak-Szałowska, M. Stahl, Prawo administracyjne. Pojęcia, instytucje, zasady $w$ teorii i orzecznictwie, Warszawa 2000, s. 98-99.

${ }_{5}^{5}$ T. Zieliński, Nowy ład pracy - rzeczywistość i wizja przyszłości, w: M. Matey, Nowy ład pracy w Polsce i w Europie, Warszawa 1997, s. 19.

${ }^{6}$ H. Szewczyk, Równość płci w zatrudnieniu, Warszawa 2017, s. 21-29; Z. Góral, Zasada równości pracowników w dziedzinie zatrudnienia i niedyskryminacji w zatrudnieniu, w: Zarys systemu prawa pracy, K.W. Baran (red.), t. I, Część ogólna prawa pracy, Warszawa 2010, s. 622 i n. oraz powołana tam literatura. 
wyeliminowanie dyskryminacji w przypadku pracowników niepełnosprawnych nie wystarczy. Samym tylko równym traktowaniem pracowników pełnosprawnych i niepełnosprawnych nie zapewni się tym ostatnim równości szans. Trzeba przyznać więc rację M. Taniewskiej-Banackiej, gdy stwierdza, że „równość szans wymaga zatem nie biernej i w pełni akceptującej ludzi niepełnosprawnych postawy, lecz szczególnych działań, które umożliwić mają usuwanie stawianych przez lata barier"7. Przecież nawet jeśli nie zostaną oni potraktowani w sposób inny niż pracownicy, którzy są pełnosprawni, to i tak ich pozycja już na starcie jest gorsza. Osobie z niepełnosprawnością najczęściej trudniej jest realizować stawiane przez pracodawcę wymagania czy konkurować z osobami zdrowymi. Właśnie dlatego, aby wyeliminować tę różnicę, ustawodawca w ustawie o rehabilitacji zawodowej i społecznej oraz zatrudnianiu osób niepełnosprawnych ${ }^{8}$ rozszerzył pojęcie zakazu dyskryminacji nie tylko na zakaz określonego postępowania, lecz również nakaz określonego pozytywnego działania ${ }^{9}$. Chodzi tu o obowiązek zapewnienia konkretnych usprawnień dla osoby niepełnosprawnej. Celem regulacji jest więc ułatwienie wykonywania pracy osobie niepełnosprawnej tak, by posiadana przez nią niepełnosprawność nie stanowiła bariery dla podjęcia danej pracy. Wyraźne podkreślenie w wyżej wymienionej ustawie, że brak podejmowanych przez pracodawcę pozytywnych działań na rzecz pracowników niepełnosprawnych stanowi naruszenie zasady równego traktowania, należy ocenić bardzo pozytywnie. Brak tej regulacji mógłby bowiem powodować, że pasywna postawa pracodawcy nie mogłaby być sankcjonowana, nie zawsze bowiem mieści się ona w definicji zakazu dyskryminacji w rozumieniu Rozdziału IIa Kodeksu pracy $^{10}$, jedynie czasem mogłaby być potraktowana jako dyskryminacja pośrednia.

M. Taniewska-Banacka, Przyjęte w Polsce rozwiązania prawne zmierzajace do zagwarantowania osobom niepetnosprawnym równości szans, w: Jednolitość orzecznictwa samorządowych kolegiów odwoławczych w zakresie pomocy społecznej, S. Nitecki (red.), Bielsko-Biała 2005, s. 39.

8 Por. art. $23^{\mathrm{a}}$ ust. 1 ustawy z dnia 27 sierpnia 1997 r. o rehabilitacji zawodowej i społecznej oraz zatrudnianiu osób niepełnosprawnych (tekst jedn. Dz. U. z 2016 r., poz. 2046), zgodnie z którym „Pracodawca jest obowiązany zapewnić niezbędne racjonalne usprawnienia dla osoby niepełnosprawnej pozostającej z nim w stosunku pracy, uczestniczącej w procesie rekrutacji lub odbywającej szkolenie, staż, przygotowanie zawodowe albo praktyki zawodowe lub absolwenckie. Niezbędne racjonalne usprawnienia polegają na przeprowadzeniu koniecznych w konkretnej sytuacji zmian lub dostosowań do szczególnych, zgłoszonych pracodawcy potrzeb wynikających z niepełnosprawności danej osoby, o ile przeprowadzenie takich zmian lub dostosowań nie skutkowałoby nałożeniem na pracodawcę nieproporcjonalnie wysokich obciążeń (...)". Jednocześnie w ust. 3 wyżej przywołanego artykułu wyraźnie stwierdzono, że „Niedokonanie niezbędnych racjonalnych usprawnień, o których mowa w ust. 1, uważa się za naruszenie zasady równego traktowania $\mathrm{w}$ zatrudnieniu $\mathrm{w}$ rozumieniu przepisów art. $18^{\text {3a }} \S 2-5$ ustawy $\mathrm{z}$ dnia 26 czerwca 1974 r. - Kodeks pracy".

9 Nawiasem mówiąc, przepis art. 23 ust. 1 ustawy o rehabilitacji zawodowej i społecznej oraz zatrudnianiu osób niepełnosprawnych stanowi wzorcowy przykład implementacji dyrektywy Rady 2000/78/ WE z dnia 27 listopada 2000 r. ustanawiającej ogólne warunki ramowe równego traktowania w zakresie zatrudnienia i pracy. Nie jest to zatem oryginalne rozwiązanie polskiego prawodawcy.

${ }_{10} \mathrm{Na}$ temat pojmowania zakazu dyskryminacji w zatrudnieniu w świetle art. $18^{3 \mathrm{a}}$ Kodeksu pracy zob. między innymi: P. Korus, w: Kodeks pracy. Komentarz, A. Sobczyk (red.), Warszawa 2017; W. Muszalski, w: Tenże, Kodeks pracy. Komentarz, Warszawa 2015; J. Wratny, Kodeks pracy. Komentarz, Warszawa 2017; Z. Góral, w: System prawa pracy, K.W. Baran (red.), t. I, Część ogólna, Warszawa 2017; M. Tomaszewska, 


\section{Aspekty prawno-porównawcze dotyczące pomocy państwa osobom niepełnosprawnym}

Problematyka praw pracowników niepełnosprawnych jest przedmiotem wielu regulacji prawa międzynarodowego. Istotna ich część została ratyfikowana przez Polskę. Wydaje się, że przede wszystkim należy wskazać na stanowiącą część dorobku normatywnego Rady Europy Europejską Kartę Społeczną (EKS) ${ }^{11}$, w której już w preambule stanowi się, iż osoby niepełnosprawne mają prawo do szkolenia zawodowego, rehabilitacji oraz readaptacji zawodowej i społecznej, bez względu na przyczynę i rodzaj ich inwalidztwa. W części merytorycznej karty jednym z podstawowych uprawnień jest prawo osób niepełnosprawnych fizycznie lub umysłowo do szkolenia zawodowego, rehabilitacji oraz readaptacji zawodowej i społecznej (art. 15). W celu jego realizacji umawiające się strony zobowiązały się podjąć konieczne środki w celu zapewnienia osobom niepełnosprawnym ułatwień szkoleniowych (w tym, jeżeli to konieczne, utworzenia wyspecjalizowanych instytucji publicznych lub prywatnych) oraz podjąć odpowiednie środki w celu zatrudniania osób niepełnosprawnych (chodzi o powołanie wyspecjalizowanych służb pośrednictwa pracy, ułatwianie podejmowania pracy chronionej oraz podejmowanie środków zachęcających pracodawców do zatrudniania osób niepełnosprawnych). Podobne uprawnienia (do poradnictwa zawodowego oraz szkolenia zawodowego) zostały uregulowane w art. 9 (umawiające się strony zobowiązują się zapewnić lub popierać, w miarę potrzeby, służby, które będą udzielać pomocy wszystkim osobom, w tym osobom niepełnosprawnym...) i 10 (umawiające się strony zobowiązują się zapewnić lub popierać, w miarę potrzeby, szkolenie techniczne i zawodowe wszystkich osób, w tym osób niepełnosprawnych...) EKS.

Szczególną rolę dla określenia statusu prawnego osób niepełnosprawnych odgrywa również Konwencja Międzynarodowej Organizacji Pracy nr 159 dotycząca rehabilitacji zawodowej i zatrudniania osób niepełnosprawnych ${ }^{12}$. Konwencja za osobę niepełnosprawną uznaje osobę, której możliwości uzyskania i utrzymania odpowiedniego zatrudnienia oraz awansu zawodowego są znacznie ograniczone w wyniku ubytku zdolności fizycznych lub umysłowych, właściwie orzeczonego. Podstawowym celem tej konwencji jest zapobieganie wykluczeniu społecznemu osób niepełnosprawnych przez prowadzenie odpowiedniej polityki ukierunkowanej na rehabilitację zawodową. Celem tej rehabilitacji jest natomiast umożliwienie osobie niepełnosprawnej uzyskania i utrzymania odpowiedniego zatrudnienia, awansu zawodowego, aby w ten sposób ułatwić jej włączenie się lub ponowne włączenie się do społeczeństwa. Artykuł 4 konwencji stanowi ponadto, że prowadzona polityka oparta będzie na równości szans pracowników: niepełnosprawnych i tych

\footnotetext{
w: Kodeks pracy. Komentarz, K.W. Baran (red.), Warszawa 2015; A. Świątkowski, Kodeks pracy. Komentarz, Warszawa 2016.

${ }^{11}$ Europejska Karta Społeczna z dnia 18 października 1961 r. (Dz. U. z 1999 r., Nr 8, poz. 67 ze zm.).

12 Konwencja nr 159 Międzynarodowej Organizacji Pracy z dnia 20 czerwca 1983 r. (Dz. U. z 2005 r., $\mathrm{Nr} 43$, poz. 412).
} 
całkowicie zdrowych. Istotnym obowiązkiem państw, które przyjęły konwencję, jest tworzenie służb poradnictwa zawodowego, szkolenia zawodowego, pośrednictwa pracy, zatrudnienia i innych podobnych służb, umożliwiających osobom niepełnosprawnym uzyskanie i utrzymanie zatrudnienia oraz awans zawodowy.

Biorąc pod uwagę zakres przedmiotowy uregulowań prawnych dotyczących osób niepełnosprawnych, kluczowa rola przypada jednak przyjętej przez Zgromadzenie Ogólne ONZ Konwencji o prawach osób niepełnosprawnych ${ }^{13}$. Ma ona znacznie szerszy zakres przedmiotowy niż wyżej wymienione konwencje, odnosząc się właściwie do wszystkich sfer życia osób niepełnosprawnych. W interesującym nas zakresie w konwencji szczegółowo uregulowano problematykę pracy i zatrudnienia (prawo do pracy osób niepełnosprawnych, popieranie zatrudnienia, rozwoju zawodowego, popieranie programów rehabilitacji zawodowej, szkolenia zawodowego, pomoc w znalezieniu i utrzymaniu zatrudnienia).

Prawo UE także szeroko odnosi się do problematyki ochrony osób niepełnosprawnych. Pomijając już fakt, że w 2010 r. UE przystąpiła do omówionej wyżej Konwencji o prawach osób niepełnosprawnych, kwestie te są przedmiotem zainteresowania przede wszystkim Karty Praw Podstawowych Unii Europejskiej oraz Traktatu o funkcjonowaniu Unii Europejskiej ${ }^{14}$. Traktat o funkcjonowaniu Unii Europejskiej w art. 10 i 19 przewiduje ogólny zakaz dyskryminacji ze względu na niepełnosprawność. Zważywszy na fakt, że przepisy te nie wywołują skutku bezpośredniego, czyli nie stanowią podstawy do formułowania jakichkolwiek praw podmiotowych wobec jednostki, Rada Unii Europejskiej wydała 27 listopada 2000 r. dyrektywę nr 2000/78/WE ustanawiającą ogólne warunki ramowe równego traktowania w zakresie zatrudnienia i pracy ${ }^{15}$. Podstawowym celem tej dyrektywy jest wyznaczenie ogólnych ram walki z dyskryminacją w odniesieniu do zatrudnienia i pracy ze względu między innymi na niepełnosprawność ${ }^{16}$. W orzecznictwie TS UE pojęcie niepełnosprawności na gruncie wyżej wymienionej dyrektywy należy rozumieć jako ograniczenie wynikające w szczególności z trwałego osłabienia funkcji fizycznych, umysłowych lub psychicznych, które w oddziaływaniu z różnymi barierami może utrudniać danej osobie pełny i skuteczny udział w życiu zawodowym na równi $z$ innymi pracownikami ${ }^{17}$. Oprócz TF UE innym aktem normatywnym zaliczanym do pierwotnego prawa unijnego jest Karta Praw Podstawowych, której art. 26 przewiduje prawo osób niepełnosprawnych do korzystania ze środków mających

${ }^{13}$ Konwencja o prawach osób niepełnosprawnych z dnia 13 grudnia 2006 r. (Dz. U. z 2012 r., poz. 1169).

14 Dz. Urz. UE 2016 C, Nr 202, s. 1.

15 Dz. Urz. UE 2000 L, Nr 303, s. 16.

${ }^{16}$ Szerzej na temat tej dyrektywy zob. J. Maliszewska-Nienartowicz, Dyskryminacja ze względu na religię, niepetnosprawnośc, wiek lub orientację seksualna. Dyrektywa 2000/78 i orzecznictwo TS UE. Komentarz, Warszawa 2013.

17 Zob. wyrok TS UE z dnia: 18 grudnia 2014 r. w spr. C-354/13 Kaltofta, Dz. Urz. UE C z 2015 r., Nr 65, s. 7; 18 marca 2014 r. w spr. C-363/12 Z przeciwko A Government Department, Dz. Urz. UE C z 2014 r., Nr 142, s. 7. 
zapewnić im samodzielność, integrację społeczną i zawodową oraz udział w życiu społeczności. Przytoczone powyżej regulacje prawa UE pozwalają na sformułowanie wniosku, że podstawową formą wsparcia osób niepełnosprawnych jest przeciwdziałanie wykluczeniu społecznemu, czemu przede wszystkim ma służyć pomoc w aktywnym życiu zawodowym. Promowane są zatem aktywne środki aktywizacji, które w założeniu mają pomóc w odnalezieniu się na rynku pracy. Zastosowanie takich środków możliwe jest jednak wyłącznie w przypadku niepełnosprawności umożliwiającej aktywność zawodową. W przypadku osób, których rodzaj niepełnosprawności nie pozwala na taką aktywność, ochronę zapewnia powoływana wyżej Konwencja o prawach osób niepełnosprawnych. Warto w tym miejscu podkreślić, że zakres realizacji tych uprawnień pozostawiony jest, o czym mowa niżej, znacznej swobodzie regulacyjnej państw członkowskich Unii Europejskiej.

Biorąc pod uwagę krajowy poziom ochrony praw osób niepełnosprawnych, należy skonstatować, że ochrona tych osób została przewidziana w konstytucjach tylko kilku współczesnych państw demokratycznych. Podkreślić przy tym trzeba, że poszczególne regulacje albo wprost odnoszą się do niepełnosprawności, albo posługują się pojęciem inwalidztwa. Przykładowo wskazać można na konstytucje następujących państw: Estonii ( $\$ 28$ - „osoby niepełnosprawne są pod szczególną opieką państwa i samorządów lokalnych”); Luksemburga (art. 11 ust. 1 - „ustawa reguluje, co się tyczy zasad, zabezpieczenie społeczne, ochronę zdrowia, prawa pracowników, walkę z ubóstwem i integrację społeczną obywateli dotkniętych inwalidztwem”); Rumunii (art. 50 - „osoby niepełnosprawne korzystają ze szczególnej opieki, państwo zapewnia realizację ogólnokrajowej polityki równości szans, zapobiegania i leczenia niepełnosprawności, mającej na celu efektywny udział osób niepełnosprawnych w życiu społecznym, szanując prawa i obowiązki przysługujące ich rodzinom i opiekunom”); Włoch (art. 38 ust. 3 - „niezdolni do pracy i inwalidzi mają prawo do edukacji i przysposobienia zawodowego"); Czech (art. 29 ust. 2 Karty Podstawowych Praw i Wolności - „osoby zdrowotnie upośledzone mają prawo do szczególnej ochrony stosunków pracy i do pomocy w przygotowaniu do zawodu"); Bułgarii (art. 48 ust. 2 - „państwo tworzy warunki realizacji prawa do pracy dla osób niepełnosprawnych fizycznie i psychicznie"). Z przytoczonych przykładów wyraźnie wynika, że na poziomie konstytucyjnym reguluje się zarówno zadania państwa w sferze zapewnienia praw osobom niepełnosprawnym, jak również prawa podstawowe tych osób.

Regulacje konstytucyjne dotyczące problematyki zatrudniania osób niepełnosprawnych i realizacji ich szczególnych uprawnień są uszczegóławiane i rozwijane na poziomie ustawowym. Biorąc to pod uwagę, we współczesnej Europie funkcjonują różne modele polityki zatrudnienia osób niepełnosprawnych. W ich ramach państwa stosują różne formy interwencji i wsparcia kierowane do pracodawców i innych podmiotów rynku pracy oraz do osób niepełnosprawnych. Wspólnym celem tych rozwiązań jest z jednej strony pomoc w zatrudnieniu, z drugiej zaś aktywizowanie i rehabilitacja zawodowa osób niepełnosprawnych. Szczególnie istotne wydają się regulacje kierowane do pracodawców, które są związane z nakładaniem na nich określonych obowiązków dotyczących zatrudniania osób niepełnosprawnych. Dwa podstawowe modele to system kwotowy 
i system oparty na prawach obywatelskich ${ }^{18}$. We współczesnej Europie dominuje polityka zatrudnienia oparta na systemie kwotowym. Występuje ona nie tylko w naszym kraju, ale także między innymi w Austrii, Francji, Hiszpanii, Niemczech, Włoszech. System ten zobowiązuje pracodawców, którzy nie zatrudniają wymaganej liczby niepełnosprawnych pracowników, do opłacania składki (będącej rodzajem sankcji) na wydzielony fundusz. Pracodawcy osiągający normę zatrudnienia niepełnosprawnych pracowników mogą z kolei uzyskać dodatkowe wsparcie finansowe ze środków publicznych. Tego typu rozwiązania mają na celu wymuszenie na pracodawcach funkcjonujących na otwartym rynku pracy tworzenia nowych i utrzymywania istniejących miejsc pracy. Odbywa się to na drodze swego rodzaju przymusu ekonomicznego. Polityka zatrudnienia oparta na prawach obywatelskich polega z kolei na egzekwowaniu konstytucyjnie zagwarantowanego prawa do pracy czy zakazu dyskryminacji. Występuje między innymi w takich państwach, jak Wielka Brytania, Irlandia, Szwecja, Holandia. W modelu tym zrównanie prawa do pracy i wyrównanie szans w zatrudnieniu są konsekwencją podzielanych w społeczeństwie wartości wzmocnionych przez ustawodawstwo antydyskryminacyjne. Polityka zatrudnienia może też przybrać inną postać i wykorzystywać rozwiązania mieszane. Tylko tytułem przykładu można wskazać politykę zatrudnienia opartą na motywowaniu pracodawców, odwołującą się do ustawodawstwa antydyskryminacyjnego i obowiązku przystosowania miejsc pracy oraz do szeroko rozumianej opinii społecznej. Rozwiązania te występują między innymi w Danii i Norwegii. System ten opiera się na dobrowolności działań pracodawców, gdyż nie ma sankcji finansowych za niezatrudnianie niepełnosprawnych pracowników. Pracodawcy motywowani są natomiast za pomocą różnych kampanii informacyjnych i wspierani różnymi instrumentami, między innymi w ramach aktywnej polityki rynku pracy czy zabezpieczenia społecznego.

\section{Aspekty historyczne regulacji dotyczących pomocy państwa osobom niepełnosprawnym}

Na gruncie poprzednio obowiązujących w Polsce ustaw zasadniczych brak regulacji wprost odnoszących się do ochrony praw osób niepełnosprawnych. Konstytucja marcowa pomijała zupełnie tę problematykę. W okresie międzywojennym obowiązek udzielania wsparcia osobom niepełnosprawnym regulowała jedynie ustawa o pomocy społecznej z 1923 r. ${ }^{19}$ Określała ona zasady opieki nad inwalidami, kalekami, osobami upośledzonymi umysłowo i niezdolnymi do pracy. Podkreślała ona konieczność usamodzielniania osób niepełnosprawnych, a także udzielania przez państwo aktywnej pomocy mającej na celu przywrócenie zdolności do pracy, wsparcia przy podjęciu pracy czy zorganizowaniu

18 Szerzej na ten temat zob. między innymi: M.A. Paszkowicz, Wybrane aspekty funkcjonowania osób $z$ niepetnosprawnościami, Zielona Góra 2009 i M. Garbat, Zatrudnianie i rehabilitacja zawodowa osób z niepetnosprawnościq w Europie, Zielona Góra 2012.

${ }_{19}$ Ustawa z dnia 16 sierpnia 1923 r. o pomocy społecznej (Dz. U. z 1923 r., Nr 92, poz. 726). 
własnego warsztatu pracy. Konstytucja PRL z 1952 r. ${ }^{20}$ dotykała problematyki osób niepełnosprawnych jedynie w kontekście prawa do ochrony zdrowia ${ }^{21}$.

Warto w tym miejscu podkreślić, że problematyka niepełnosprawności nie była w okresie Polski Ludowej przedmiotem szerszych działań legislacyjnych. Mimo eksponowania praw socjalnych jednostki w państwie socjalistycznym nie stawiano na rozwój pomocy społecznej i udzielanie pomocy osobom niepełnosprawnym. Propagowano obowiązek pracy $\mathrm{z}$ jednoczesnym bardzo niechętnym podchodzeniem do osób, które nie były w stanie się utrzymać. Niemal całkowicie pomijano działania na rzecz usamodzielniania i aktywizacji osób niepełnosprawnych. Do nielicznych form wsparcia tego rodzaju można by jedynie zaliczyć poradnictwo rehabilitacyjno-zawodowe czy zapewnianie pracy chronionej. Dopiero transformacja ustrojowa przyczyniła się do powolnych zmian prawno-organizacyjnych, które zaowocowały ostatecznie uchwaleniem ustawy o zatrudnianiu i rehabilitacji osób niepełnosprawnych ${ }^{22}$.

\section{Obowiązki państwa wobec pracowników (w tym pracowników niepełnosprawnych) związane z prowadzeniem odpowiedniej polityki zatrudnienia (uwagi na tle art. 65 ust. 5 Konstytucji Rzeczpospolitej Polskiej)}

Art. 65 ust. 5 Konstytucji RP proklamuje obowiązki nałożone na władzę publiczną, które ta ma wykonywać $\mathrm{w}$ interesie pracowników. Ich realizacja ma polegać na prowadzeniu polityki zmierzającej do pełnego i produktywnego zatrudnienia poprzez realizowanie programów zwalczania bezrobocia. Jak słusznie zauważa A. Sobczyk, omawiany przepis konstytucji stanowi jedynie pośredni dowód na to, że praca ma istotne znaczenie socjalne ${ }^{23}$. Skoro władze publiczne mają tak silny konstytucyjny obowiązek kreowania miejsc pracy, to niewątpliwie z powodu roli pracy w życiu społecznym ${ }^{24}$.

Powszechnie wiadomo, że zjawisko bezrobocia niesie z sobą wiele negatywnych skutków. Powoduje powstawanie ubóstwa, a także prowadzi do wykluczenia społecznego

${ }^{20}$ Konstytucja Polskiej Rzeczpospolitej Ludowej z dnia 22 lipca 1952 r. (tekst. jedn. Dz. U. z 1976 r., $\mathrm{Nr} 7$, poz. 36).

${ }^{21}$ Art. 70 ust. 2 pkt 2 stanowił, że coraz pełniejszemu urzeczywistnianiu prawa do ochrony zdrowia oraz do pomocy w razie choroby lub niezdolności do pracy służy rozwój organizowanej przez państwo ochrony zdrowia oraz podnoszenie poziomu zdrowotnego ludności, bezpłatna pomoc lekarska dla wszystkich ludzi pracy i ich rodzin, stałe polepszanie warunków bezpieczeństwa, ochrony i higieny pracy, szeroko rozwinięte zapobieganie chorobom i ich zwalczanie, opieka nad inwalidami.

${ }^{22}$ Ustawa z dnia 9 maja 1991 r. o zatrudnianiu i rehabilitacji osób niepełnosprawnych (Dz. U. z 1991 r., Nr 46, poz. 201).

${ }^{23}$ Przepisem wprost dowodzącym istnienia zasady ochrony przed niedostatkiem przez pracę jest jedynie art. 65 ust. 4 konstytucji przewidujący gwarancję wynagrodzenia minimalnego.

24 A. Sobczyk, Prawo pracy w świetle Konstytucji RP, t. I, Teoria publicznego i prywatnego indywidualnego prawa pracy, Warszawa 2013, s. 145. 
bezrobotnych i ich rodzin. Właśnie dlatego problematyka przeciwdziałania temu zjawisku poruszana jest w wielu aktach prawa międzynarodowego, w tym w Deklaracji Praw Człowieka i Obywatela, Europejskiej Karcie Socjalnej czy Konwencji Międzynarodowej Organizacji Pracy nr 122 dotyczącej polityki zatrudnienia ${ }^{25}$. Należy zaznaczyć, że katalog konkretnych działań, jakich polski ustrojodawca wymaga od władz publicznych realizujących tę politykę, nie jest katalogiem enumeratywnym. Tak więc ustrojodawca, wymieniając: organizowanie i wspieranie poradnictwa i szkolenia zawodowego oraz robót publicznych i prac interwencyjnych, określa jedynie minimum obowiązków organów władzy publicznej. Pogląd ten znajduje potwierdzenie w orzecznictwie Trybunału Konstytucyjnego. W wyroku z dnia 13 marca $2000 \mathrm{r}$. trybunał zwrócił uwagę na to, że przepis art. 65 ust. 5 Konstytucji RP jest przepisem programowym, wskazującym na zasadnicze kierunki działania władz publicznych ${ }^{26}$. Pogląd ten nie spotkał się z pełną akceptacją doktryny, co wydaje się zrozumiałe z uwagi na fakt, że unormowania dotyczące zasad polityki państwa mają bezpośrednią skuteczność prawną ${ }^{27}$. Warto też zauważyć, że TK w tym samym wyroku stwierdził, iż trudne do akceptacji byłoby zapatrywanie, że normy programowe nie dają podstaw do odnalezienia w nich żadnych obowiązków organów publicznych. Podsumowując rozważania dotyczące charakteru prawnego art. 65 ust. 5 konstytucji, należy skonstatować, że w przepisie tym ustrojodawca wyraźnie określił cel (pełna produktywizacja zatrudnienia), adresata (władze publiczne) oraz nakazane zachowanie, zmierzające do osiągnięcia tego celu (realizowanie programów zwalczania bezrobocia, w tym organizowania i wspierania poradnictwa i szkolenia zawodowego ${ }^{28}$ oraz robót publicznych i prac interwencyjnych) ${ }^{29}$.

W tym miejscu należy postawić pytanie o sposób prowadzenia przez państwo polityki zatrudnienia. Wydaje się, że jej realizacja powinna oznaczać takie ukształtowanie polityki państwa w dziedzinie ekonomicznej i socjalnej, która zapewni maksymalizację wyników w dziedzinie zwalczania bezrobocia. Warto przy tym zauważyć, że nie oznacza to absolutnego priorytetu polityki zatrudnienia w państwie. Państwo nie może prowadzić jej kosztem innych dziedzin. Celem polityki państwa w dziedzinie zatrudnienia powinno być to, by osiągnąć jak najefektywniejsze wyniki przy racjonalnych kosztach. Czy zatem dopuszczalne byłoby prowadzenie takich działań przez organy władzy publicznej, które skutkowałyby wzrostem bezrobocia? Wydaje się, że tak, zważywszy, że - jak słusznie

${ }^{25}$ Konwencja MOP z dnia 9 lipca 1964 r. nr 122 (Dz. U. z 1967 r., Nr 8, poz. 31).

${ }^{26}$ Wyrok TK z dnia 13 marca 2000 r., sygn. akt K 1/99, OTK 2000, Nr 2, poz. 59.

27 J. Oniszczuk, w: Zarys systemu prawa pracy, K.W. Baran (red.), t. I, Warszawa 2010, s. 317.

${ }^{28}$ Warto w tym miejscu zwrócić uwagę na treść art. 3 Konwencji MOP nr 140 dotyczącej płatnego urlopu szkoleniowego, przyjętej w Genewie 24 czerwca 1974 r. (Dz. U. z 1979 r., Nr 16, poz. 100). Przepis ten stanowi, że szkolenia mogą służyć awansowaniu pracowników w zakresie spraw osobistych, społecznych i kulturalnych, a polityka państwa w przedmiocie szkoleń powinna zmierzać do popierania odpowiedniego, stałego kształcenia i szkolenia, pomagając pracownikom w przystosowywaniu się do współczesnych wymagań.

29 Z. Czeszejko-Sochacki, Skarga konstytucyjna w prawie polskim, Przegląd Sejmowy 1998, 1, s. 38. 
zauważył Trybunał Konstytucyjny - prowadzenie polityki zatrudnienia jest tylko jednym z konstytucyjnych celów polityki socjalnej państwa ${ }^{30}$.

Biorąc powyższe pod uwagę, należałoby zadać pytanie o dopuszczalność wnoszenia roszczeń, gdy władza nie wypełnia zadań prowadzących do produktywnego zatrudnienia. Uważam, że skoro obowiązek ten został zagwarantowany w ustawie zasadniczej, przy czym ta nie przesądziła, czy prawne środki polityki zatrudnienia mają być określone w ustawie, to obywatele powinni mieć możliwość wnoszenia roszczeń przynajmniej w zakresie konstytucyjnego minimum, gdy obowiązek ten nie jest przez władze wypełniany ${ }^{31}$. Skoro obywatele zobligowani są do wypełniania swoich obowiązków wobec państwa, to państwo również powinno to czynić wobec swoich obywateli.

Prowadzona przez władze publiczne polityka zatrudnienia ma w myśl art. 65 ust. 5 konstytucji zmierzać do pełnego, produktywnego zatrudnienia. Stanowisko doktryny jest tutaj właściwie jednomyślne. Otóż uzyskanie pełnego i jednocześnie produktywnego (racjonalnego) zatrudnienia wydaje się możliwe jedynie w teorii, ponieważ produktywność zakłada istnienie pewnego marginesu bezrobocia, co uniemożliwia osiągnięcie stanu pełnego zatrudnienia ${ }^{32}$. W tym miejscu należałoby postawić pytanie, czym jest pełne, produktywne zatrudnienie. Zważywszy na fakt, że jest to pojęcie z zakresu ekonomii, powstają trudności w prawidłowym zdekodowaniu zawartej w przepisie normy prawnej. Pełne, produktywne zatrudnienie nie oznacza absolutnie dążenia do zupełnej likwidacji bezrobocia. Przesłankę pełnego zatrudnienia należy łączyć raczej $\mathrm{z}$ produktywnością (racjonalnością). Nie ulega zatem wątpliwości, że użyty w ustawie zasadniczej zwrot oznacza dążenie do osiągnięcia zatrudnienia w danych warunkach optymalnego, nie zaś pełnego zatrudnienia faktycznego. Spoglądając na ten problem z perspektywy pracowników niepełnosprawnych, należy zauważyć, że państwo, dążąc do pełnego produktywnego zatrudnienia, nie może z jednej strony dyskryminować tej grupy pracowników, ale z drugiej nie może za wszelką cenę dążyć do likwidacji bezrobocia w tej grupie. Podejmowane działania muszą zmierzać do osiągnięcia optymalnego stanu zatrudnienia tak pracowników pełnosprawnych, jak i niepełnosprawnych.

Organy władzy publicznej, prowadząc politykę zmierzającą do pełnego, produktywnego zatrudnienia, powinny podejmować działania aktywizujące życie gospodarcze. W przykładowym katalogu działań podejmowanych przez państwo zostały wymienione takie czynności, jak: organizowanie i wspieranie poradnictwa i szkolenia zawodowego oraz organizowanie robót publicznych i prac interwencyjnych. Jak widać, nie chodzi o to, aby państwo zwalczało bezrobocie, wyłącznie zapewniając miejsca pracy. Nawet organizowanie robót publicznych czy prac interwencyjnych nie ma bezpośrednio na celu zmniejszenia bezrobocia, ale aktywizację osób pozostających bez pracy. Z punktu widzenia osób niepełnosprawnych szczególne znaczenie mają wspieranie poradnictwa i szkolenia zawodowego. To właśnie doradztwo zawodowe stanowi bowiem współcześnie jeden

30 Zob. wyrok TK z dnia 21 marca 2005 r., sygn. akt P 5/04, OTK-A 2005, Nr 3, poz. 26.

31 Zob. też A. Sobczyk, Prawo pracy..., s. 146.

32 Zob. W. Perdeus, w: Zarys systemu prawa pracy, K.W. Baran (red.), t. I, Warszawa 2010, s. 87. 
z istotniejszych składników skutecznej rehabilitacji zawodowej. Dzięki konsekwentnym działaniom podejmowanym wobec osób z niepełnosprawnością udaje się im pomóc w wyborze najlepszego dla nich zawodu, jak również w zmianie obecnie wykonywanego zawodu. Niezależnie od tego podstawowym celem polskiej polityki zatrudnienia osób niepełnosprawnych powinno być promowanie zatrudnienia tych osób przede wszystkim na otwartym rynku pracy, a także zapewnienie równości szans w dostępie i utrzymaniu zatrudnienia. Preferowanie otwartego rynku pracy nie oznacza przy tym, co bardzo istotne, likwidacji, lecz jedynie ograniczenie chronionego rynku pracy, który tworzą specjalne zakłady pracy zatrudniające osoby niepełnosprawne. Główny strumień zatrudnienia osób niepełnosprawnych powinien bowiem zostać skierowany na otwarty rynek pracy po to, by prawo do pracy osób niepełnosprawnych było w pełni realizowane. Aby prawo to zostało jednak osobom niepełnosprawnym w pełni zagwarantowane, konieczne staje się wprowadzenie przepisów antydyskryminacyjnych i upowszechnienia dobrych praktyk gwarantujących osobom niepełnosprawnym równe szanse. Najsilniej zakorzenione bariery utrudniające realizację prawa do pracy przez osoby niepełnosprawne tkwią bowiem niewątpliwie w otoczeniu społecznym. Warto w tym miejscu podkreślić, że brak równych szans w dostępie do zatrudnienia stanowi główną przyczynę ubóstwa i wykluczenia osób niepełnosprawnych. Tak rozumiane wykluczenie ekonomiczne bardzo często łączy się zaś z wykluczeniem z życia politycznego i społecznego.

\section{Obowiązki państwa związane ze wsparciem osób niepełnosprawnych (uwagi na tle art. 69 Konstytucji RP)}

Art. 69 konstytucji jest pierwszym w historii polskiego konstytucjonalizmu przypadkiem regulacji wprost i w pełni odnoszącej się do osób niepełnosprawnych. Warto w tym miejscu zauważyć, że problematyka jurydyzacji praw socjalnych osób niepełnosprawnych nie była przedmiotem dyskusji Komisji Konstytucyjnej Zgromadzenia Narodowego. Dopiero na jej posiedzeniu 16 stycznia 1997 r. została przez J. Rulewskiego zgłoszona poprawka dodania art. 66a o brzemieniu identycznym z aktualnym art. 69 Konstytucji RP. Została ona jednak odrzucona ${ }^{33}$. Do wprowadzenia do tekstu ustawy zasadniczej art. 69 doszło na posiedzeniu Zgromadzenia Narodowego 21 marca 1997 r., kiedy to została zgłoszona poprawka nr $49^{34}$.

Zgodnie z ugruntowanym orzecznictwem Trybunału Konstytucyjnego art. 69 konstytucji jest traktowany jako norma programowa statuująca zadania państwa i wyznaczająca ustawodawcy obowiązek stworzenia rozwiązań zapewniających efektywne wsparcie osób niepełnosprawnych w różnych dziedzinach życia społecznego. Wskazana regulacja konstytucyjna odsyła do ustawy, zarówno jeśli chodzi o poziom zaspokajania potrzeb

\footnotetext{
33 Zob. Biuletyn KKZN 1997, Nr 24, s. 92.

34 Na podstawie informacji dostępnych na stronie http://www.sejm.gov.pl (dostęp: 20.04.2016).
} 
osób niepełnosprawnych, jak i przedmiot regulacji, która dotyczy tego zagadnienia ${ }^{35}$. Nie statuuje on zatem na poziomie konstytucyjnym określonego poziomu świadczeń, ich form, konkretnego zakresu czy trybu ich uzyskiwania. Jako norma programowa art. 69 konstytucji nie przyznaje zatem jednostkom roszczeń do żadnych określonych świadczeń pozytywnych, chociaż może stanowić podstawę roszczeń o charakterze negatywnym, tj. o zaniechanie działań uniemożliwiających urzeczywistnienie wyznaczonego celu. W wypadku realizacji takich norm ustawodawcy przysługuje daleko idąca swoboda, ograniczona jedynie przez wymóg respektowania zasad i wartości konstytucyjnych. W tych granicach ustawodawca, wykonując obowiązek zapewnienia pomocy osobom niepełnosprawnym, samodzielnie decyduje o wyborze określonego modelu systemu zabezpieczenia społecznego, formach i zakresie udzielanego wsparcia, mając przy tym na uwadze zachowanie równowagi budżetowej. Dzieje się tak dlatego, że w przepisie tym znalazło się bardzo czytelne odesłanie do ustawy, a praw określonych w nim można dochodzić wyłącznie $\mathrm{w}$ granicach określonych w ustawie. Tak więc, co do zasady, nie ma możliwości kwestionowania przed TK sposobu ich realizacji. Tylko w przypadku całkowitego zaniechania bądź podejmowania działań pozornych możliwe byłoby formułowanie zarzutu niezgodności z art. 69 konstytucji. Nie można tu jednak mówić o pełnej dowolności, bowiem $\mathrm{z}$ ratyfikowanych aktów prawa międzynarodowego oraz regulacji prawa UE wynika, że zakres obowiązków ustawodawcy zwykłego został dość istotnie skonkretyzowany.

Biorąc powyższe pod uwagę, art. 69 konstytucji nie stanowi zatem źródła konstytucyjnego prawa podmiotowego. Według L. Garlickiego jest tak dlatego, że w przepisie tym nie znalazło się sformułowanie o „prawie do.... Uzasadnienie to wydaje się nieprzekonujące, zważywszy na fakt, że podobnie zredagowany art. 19 konstytucji stanowi w ocenie Trybunału Konstytucyjnego źródło prawa podmiotowego ${ }^{36}$. Wydaje się, że rację ma K. Ślebzak, uznając za argument przemawiający za brakiem prawa podmiotowego $\mathrm{w}$ art. 69 Konstytucji RP - treść art. 81 konstytucji. Jego zdaniem przepis ten przesądza, że praw określonych między innnymi w art. 69 można dochodzić jedynie w granicach określonych w ustawie (chociaż użycie w odniesieniu do art. 69 pojęcia "prawa” nie do końca jest uprawnione $)^{37}$. Zasadność tego poglądu wydaje się potwierdzać także bogate orzecznictwo Trybunału Konstytucyjnego. Jego zdaniem art. 69 konstytucji nie wyraża żadnych roszczeń, które materialno-prawnie dałyby się określić ${ }^{38}$.

Art. 69 konstytucji stanowi zobowiązanie władzy publicznej do wspierania osób niepełnosprawnych. W wyroku z 23 października 2007 r. Trybunał Konstytucyjny podkreślił,

${ }_{35}$ Por. wyroki Trybunału Konstytucyjnego z: 16 marca 1999 r., sygn. K 35/98, OTK ZU nr 3/1999, poz. 37; 23 października 2007 r., sygn. P 28/07, OTK ZU nr 9/A/2007, poz. 106; 19 kwietnia 2011 r., sygn. P 41/09, OTK ZU nr 3/A/2011, poz. 25; 20 grudnia 2012 r., sygn. K 28/11, OTK ZU nr 11/A/2012, poz. 37.

${ }^{36}$ Por. wyrok TK z dnia 13 listopada 2012 r., sygn. K 2/12, OTK-A 2012, Nr 10, poz. 121.

${ }^{37}$ K. Ślebzak, Komentarz do art. 69 konstytucji, w: Konstytucja RP, t. I, Komentarz do art. 1-86, M. Safjan, L. Bosek (red.), Warszawa 2016, system informacji prawnej Legalis.

${ }_{38}$ Por. orzeczenia TK z dnia: 6 września 2000 r., TS 69/00, OTK 2000, Nr 7, poz. 277; 23 października 2007 r., P 28/07, OTK-A 2007, Nr 9, poz. 106; 19 kwietnia 2011 r., P 41/09, OTK-A 2011, Nr 3, poz. 25. 
że regulacja ta odsyła do ustawy (zarówno jeśli chodzi o poziom zaspokajania potrzeb osób niepełnosprawnych, jak i przedmiot regulacji w tym zakresie). Nie można zatem tego właśnie przepisu uważać za konstytucjonalizację określonego poziomu świadczeń, ich postaci, konkretnego zakresu czy trybu uzyskiwania. Wskazany wzorzec konstytucyjny należy odczytywać jako zobowiązanie władzy publicznej do wykreowania mechanizmu realizacji zadań w nim wskazanych. Mechanizm ten musi zapewniać efektywne osiągnięcie celu $^{39}$. Ponadto trybunał zauważył, że nie ma podstaw do wąskiego rozumienia art. 69 konstytucji (określenia tylko bezpośrednich relacji pomiędzy państwem a osobami niepełnosprawnymi), którego naruszenie mogłoby polegać wyłącznie na ograniczeniu uprawnień osób niepełnosprawnych przez takie regulacje, które by bezpośrednio godziły w egzystencję, przysposobienie do pracy oraz komunikację społeczną niepełnosprawnego, przepis ten bowiem chroni niepełnosprawnych również przed praktykami prowadzącymi w sposób pośredni (niekiedy ukryty) do naruszania ich praw ${ }^{40}$.

Omawiany przepis konstytucji ma za zadanie określenie celu działań, jakie mają zostać podjęte przez władze publiczne. Mają one polegać na pomocy w zakresie: zabezpieczenia egzystencji, przysposobienia do pracy oraz komunikacji społecznej. Wydaje się, że ustrojodawcy zależało przede wszystkim na stworzeniu możliwości udziału osób niepełnosprawnych w życiu zawodowym i społecznym. Cel ten w zakresie odnoszącym się do sfery aktywności zawodowej jest realizowany przez ustawę z 27 sierpnia $1997 \mathrm{r}$. o rehabilitacji zawodowej i społecznej oraz zatrudnianiu osób niepełnosprawnych. Jak słusznie zauważa A. Sobczyk, regulacje tej ustawy „wskazują na wyjątkową determinację ustawodawcy z jednej strony oraz solidarnościowe w swej naturze obowiązki pracodawców $\mathrm{z}$ drugiej ${ }^{41}$. Przybierają one postać ekonomicznego przymusu zatrudniania, który dotyczy pracodawców zatrudniających co najmniej 25 pracowników. Zgodnie z art. 21 wyżej wymienionej ustawy pracodawca ma bowiem do wyboru albo zatrudnienie co najmniej 6\% pracowników niepełnosprawnych, albo zapłacenie składki na fundusz rehabilitacji osób niepełnosprawnych. Swego rodzaju alternatywę stanowi jeszcze wspieranie pracodawców, którzy zatrudniają pracowników niepełnosprawnych. Ustawa, nie biorąc pod uwagę rzeczywistych potrzeb pracodawców, obciąża ich swego rodzaju parapodatkiem lub ewentualnie zobowiązuje do wspierania niepełnosprawnych „w naturze". Innym przykładem jest przewidziany w art. 14 tej samej ustawy obowiązek wydzielenia przez pracodawcę odpowiednio zorganizowanego stanowiska pracy dla niepełnosprawnego ${ }^{42}$, dla którego alternatywą jest zawarta w art. 23 wpłata na rzecz funduszu piętnastokrotnego przeciętnego miesięcznego wynagrodzenia za pracownika. Nie można też pominąć przewidzianego w art. 18 ustawy o o rehabilitacji zawodowej i społecznej oraz zatrudnianiu

39 Por. wyrok TK z dnia 23 października 2007 r., sygn. P 28/07, OTK-A 2007, Nr 9, poz. 106.

${ }^{40}$ Por. wyrok TK z dnia 6 lutego 2007 r., sygn. P 25/06, OTK-A 2007, Nr 2, poz. 9.

${ }^{41}$ A. Sobczyk, Prawo pracy..., s. 152.

${ }^{42}$ Pracodawca jest zwolniony $\mathrm{z}$ tego obowiązku tylko wtedy, gdy wypadek był spowodowany spożywaniem alkoholu lub wyłączną winą pracownika w związku z naruszeniem przepisów BHP. 
osób niepełnosprawnych obowiązku zapewnienia stałej wysokości wynagrodzenia pomimo obniżenia wymiaru etatu związanego $\mathrm{z}$ niepełnosprawnością ${ }^{43}$.

Warto również pamiętać, że ochrona osób niepełnosprawnych w zakresie zabezpieczenia egzystencji nie zawsze musi być związana $\mathrm{z}$ aktywnością zawodową. $\mathrm{W}$ odniesieniu do osób niepełnosprawnych nieaktywnych zawodowo należałoby się zastanowić, czy większej ochrony nie zapewnia im art. 67 ust. 2 konstytucji, zgodnie z którym „obywatel pozostający bez pracy nie z własnej woli i niemający innych środków utrzymania ma prawo do zabezpieczenia społecznego, którego zakres i formy określa ustawa". Co prawda art. 69 konstytucji mówi o pomocy w zabezpieczeniu egzystencji, jednak w przypadku braku możliwości podjęcia jakichkolwiek działań we własnym zakresie należałoby przyjąć istnienie obowiązku władz publicznych zabezpieczenia przynajmniej minimum egzystencji. Tymczasem Trybunał Konstytucyjny w wyroku z 21 października 2014 r. uznał, że „ustawodawca nie zabezpieczył egzystencji osób niepełnosprawnych przynajmniej na poziomie minimum życiowego (...)" ${ }^{\prime 4}$. Wydaje się, że w dziedzinie zabezpieczenia egzystencji realizacja celu sformułowanego $\mathrm{w}$ art. 69 następuje na drodze ustawy z 12 marca 2004 r. o pomocy społecznej ${ }^{45}$ oraz ustawy z 28 listopada 2003 r. o świadczeniach rodzinnych ${ }^{46}$.

\section{Zakończenie}

Przedstawione powyżej rozważania poświęcone obowiązkom państwa wobec pracowników niepełnosprawnych skłaniają do pewnych refleksji.

Przede wszystkim warto zauważyć, że eliminowanie dyskryminacji pracowników niepełnosprawnych jest tylko jednym z elementów szeroko rozumianego zakazu dyskryminacji osób niepełnosprawnych w życiu codziennym. Jest ono jednak wyeksponowane w sposób szczególny w zakresie stosunków zatrudnieniowych ze względu na to, że dyskryminowanie w tym zakresie jest szczególnie dolegliwe dla osób dyskryminowanych. To właśnie dlatego państwo podejmuje konkretne działania zmierzające nie tyle do ochrony pracownika przed dyskryminacją z uwagi na jego podporządkowanie, ile do ochrony człowieka, który zmuszony jest do zarobkowania.

Przedstawione w niniejszym opracowaniu obowiązki państwa odnoszą się do wszystkich rodzajów pracy świadczonej przez osoby niepełnosprawne. W sposób oczywisty będzie to dotyczyć zatem pracy świadczonej przez pracowników, ale także pracy zleceniobiorców lub osób samozatrudnionych, pracy w gospodarstwie rolnym. Warto w tym miejscu podkreślić, że terminy „praca” i „zatrudnienie” użyte

${ }^{43}$ Por. wyrok Sądu Najwyższego z dnia 18 kwietnia 2000 r., sygn. akt III ZP 6/00, OSNP 2000, Nr 20, poz. 740 .

${ }_{44}$ Por. wyrok TK z dnia 21 października 2014 r., sygn. K 38/13, OTK-A 2014, Nr 9, poz. 104.

${ }_{45}$ Tekst jedn. Dz. U. z 2015 r., poz. 163 ze zm.

46 Tekst jedn. Dz. U. z 2015 r., poz. 114 ze zm. 
w Konstytucji RP powinny być pojmowane szerzej niż w Kodeksie pracy. Nie ulega wątpliwości, że pojęcia konstytucyjne nie mogą być interpretowane przez pryzmat definicji ustawowych. Słusznie zauważa więc A. Sobczyk, że „przedmiotem konstytucji jest ochrona wartości uniwersalnych, a nie precyzowanie konkretnego uprawnienia, które według dominującej dziś doktryny - w moim przekonaniu błędnej - ma charakter zobowiązaniowy (np. prawo do urlopu)" 47 .

Z punktu widzenia ochrony pracowników niepełnosprawnych szczególnie istotne jawią się zasady: sprawiedliwości społecznej i godności. Ze związku tych zasad można wywodzić obowiązek sprawiedliwego i równego traktowania wszystkich pracowników. Co szczególnie istotne, obowiązek ten spoczywa nie tylko na pracodawcach, lecz także na państwie, które ma stwarzać warunki zapewniające równość traktowania pracowników pełnosprawnych i niepełnosprawnych.

Nie ulega wątpliwości, że realizacja praw pracowników niepełnosprawnych nie zawsze musi polegać na zwiększaniu obciążeń pracodawców. Państwo ma zapewnić tym osobom godne życie, jednak może to czynić, także wykorzystując służby publiczne oraz mechanizmy zabezpieczenia społecznego. Nie może przerzucać obowiązku dbałości o pracownika niepełnosprawnego wyłącznie na pracodawców. Takie bowiem działanie może spowodować naruszenie istoty ich konstytucyjnych praw. Słusznie zwraca zatem uwage A. Sobczyk, że jeżeli państwo uznaje daną potrzebę pracownika (niepełnosprawnego) za istotną, to musi ją zrealizować, przy czym jeżeli nałożenie konkretnych obowiązków na pracodawcę nie wchodzi w grę, wówczas powinno ją zaspokoić bezpośrednio ${ }^{48}$. Tytułem przykładu, jeżeli pracodawca zatrudniający do 20 pracowników nie może udźwignąć ciężaru odpraw, to obowiązek ten powinno wziąć na siebie państwo, wypłacając je bezpośrednio pracownikom. Biorąc to pod uwagę, w interesie państwa jest także promowanie dialogu społecznego i zmniejszanie ustawowych obciążeń pracodawców. Jeżeli bowiem dana potrzeba pracownika zostanie w ustawie uznana za uzasadnioną, państwo będzie zobowiązane do jej zaspokojenia względem wszystkich pracowników.

Z punktu widzenia zapewnienia praw pracownikom ( $w$ tym pracownikom niepełnosprawnym) poważne wątpliwości wzbudza obecne brzmienie art. 65 ust. 5 konstytucji. Przepis te pomija bowiem zupełnie prawo bezrobotnych i poszukujących pracy do pomocy państwa w znalezieniu odpowiedniej pracy. Wydaje się to szczególnie istotne z punktu widzenia pracowników niepełnosprawnych. Jak słusznie zauważa J. Wratny, ten aspekt prawa do pracy jest nie tylko jego gwarancją, lecz może przybrać także postać prawa podmiotowego, czego aktualne brzmienie art. 65 ust. 5 konstytucji nie zapewnia ${ }^{49}$. Poza tym obecne brzmienie tego przepisu powoduje zatarcie różnicy między nakazem

47 A. Sobczyk, Prawo pracy..., s. 67.

48 Tamże, s. 160.

49 J. Wratny, Prawo do pracy - pojęcie, ocena, propozycje, w: Jedność w różnorodności. Studia z zakresu prawa pracy, zabezpieczenia społecznego i polityki społecznej. Księga pamiątkowa dedykowana Profesorowi Wojciechowi Muszalskiemu, A. Patulski, K. Walczak (red.), Warszawa 2009, s. 106-107. 
prowadzenia stosownej polityki przez państwo a prawem do świadczeń przysługującym jednostce.

\section{Bibliografia}

\section{Literatura}

Czeszejko-Sochacki Z., Skarga konstytucyjna w prawie polskim, Przegląd Sejmowy 1998, 1.

Garlicki L., Artykuł 32, w: K. Działocha, L. Garlicki, P. Sarnecki, W. Sokolewicz, J. Trzciński, Konstytucja Rzeczypospolitej Polskiej. Komentarz, t. 3, Warszawa 2003.

Góral Z., w: System prawa pracy, K.W. Baran (red.), t. I, Część ogólna, Warszawa 2017.

Góral Z., Zasada równości pracowników $w$ dziedzinie zatrudnienia i niedyskryminacji w zatrudnieniu, w: Zarys systemu prawa pracy, K.W. Baran (red.), t. I, Część ogólna prawa pracy, Warszawa 2010.

Korus P., w: Kodeks pracy. Komentarz, A. Sobczyk (red.), Warszawa 2017.

Maliszewska-Nienartowicz J., Dyskryminacja ze względu na religię, niepetnosprawność, wiek lub orientacje seksualna. Dyrektywa 2000/78 i orzecznictwo TS UE. Komentarz, Warszawa 2013.

Muszalski W., w: W. Muszalski, Kodeks pracy. Komentarz, Warszawa 2015.

Olejniczak-Szałowska E., Zasada legalności, zasada równości wobec prawa i zasada sprawiedliwości społecznej, w: Z. Duniewska, B. Jaworska-Dębska, R. Michalska-Badziak, E. Olejniczak-Szałowska, M. Stahl, Prawo administracyjne. Pojęcia, instytucje, zasady w teorii i orzecznictwie, Warszawa 2000.

Oniszczuk J., w: Zarys systemu prawa pracy, K.W. Baran (red.), t. I, Warszawa 2010.

Perdeus W., w: Zarys systemu prawa pracy, K.W. Baran (red.), t. I, Warszawa 2010.

Sobczyk A., Prawo pracy w świetle Konstytucji RP, t. I, Teoria publicznego i prywatnego indywidualnego prawa pracy, Warszawa 2013.

Szewczyk H., Równość płci w zatrudnieniu, Warszawa 2017.

Ślebzak K., Komentarz do art. 69 konstytucji, w: Konstytucja RP, t. I, Komentarz do art. 1-86, M. Safjan, L. Bosek (red.), Warszawa 2016.

Świątkowski A., Kodeks pracy. Komentarz, Warszawa 2016.

Taniewska-Banacka M., Przyjęte w Polsce rozwiązania prawne zmierzające do zagwarantowania osobom niepełnosprawnym równości szans, w: Jednolitość orzecznictwa samorzadowych kolegiów odwoławczych w zakresie pomocy społecznej, S. Nitecki (red.), Bielsko-Biała 2005.

Tomaszewska M., w: Kodeks pracy. Komentarz, K.W. Baran (red.), Warszawa 2015.

Wratny J., Kodeks pracy. Komentarz, Warszawa 2017.

Wratny J., Prawo do pracy - pojęcie, ocena, propozycje, w: Jedność w różnorodności. Studia z zakresu prawa pracy, zabezpieczenia społecznego i polityki społecznej. Ksiega pamiątkowa dedykowana Profesorowi Wojciechowi Muszalskiemu, A. Patulski, K. Walczak (red.), Warszawa 2009.

Zieliński T., Nowy ład pracy - rzeczywistość i wizja przyszłości, w: M. Matey, Nowy ład pracy w Polsce i w Europie, Warszawa 1997. 


\section{Orzecznictwo}

Orzeczenie TK z dnia 9 marca 1987 r., sygn. U 7/87, OTK 1988, cz. 1, poz. 1.

Orzeczenie TK z dnia 6 maja 1998 r., K 37/97, OTK 1998, Nr 3, poz. 33.

Orzeczenie TK z dnia 20 października 1998 r., K 7/98, OTK 1998, Nr 6, poz. 96.

Orzeczenie TK z dnia 17 maja 1999 r., P 6/98, OTK 1999, Nr 4, poz. 76.

Orzeczenie TK z dnia 21 września 1999 r., K 6/98, OTK 1999, Nr 6, poz. 117.

Orzeczenie TK z dnia 4 stycznia 2000 r., K 18/99, OTK 2000, Nr 1, poz. 1.

Orzeczenie TK z dnia 6 września 2000 r., TS 69/00, OTK 2000, Nr 7, poz. 277.

Orzeczenie TK z dnia 18 grudnia 2000 r., K 10/00, OTK 2000, Nr 8, poz. 298.

Orzeczenie TK z dnia 21 maja 2002 r., K 30/01, OTK-A 2002, Nr 3, poz. 32.

Orzeczenie TK z dnia 22 lutego 2005 r., K 10/04, OTK-A 2005, Nr 2, poz. 17.

Orzeczenie TK z dnia 18 grudnia 2008 r., K 19/07, OTK-A 2008, Nr 10, poz. 182.

Wyrok SN z dnia 18 kwietnia 2000 r., sygn. akt III ZP 6/00, OSNP 2000, Nr 20, poz. 740.

Wyrok TK z dnia 13 marca 2000 r., sygn. akt K 1/99, OTK 2000, Nr 2, poz. 59.

Wyrok TK z dnia 21 marca 2005 r., sygn. akt P 5/04, OTK-A 2005, Nr 3, poz. 26.

Wyrok TK z dnia 16 marca 1999 r., sygn. K 35/98, OTK ZU nr 3/1999, poz. 37.

Wyrok TK z dnia 23 października 2007 r., sygn. P 28/07, OTK ZU nr 9/A/2007, poz. 106.

Wyrok TK z dnia 19 kwietnia 2011 r., sygn. P 41/09, OTK ZU nr 3/A/2011, poz. 25.

Wyrok TK z dnia 20 grudnia 2012 r., sygn. K 28/11, OTK ZU nr 11/A/2012, poz. 37.

Wyrok TK z dnia 13 listopada 2012 r., sygn. K 2/12, OTK-A 2012, Nr 10, poz. 121.

Wyrok TK z dnia 6 lutego 2007 r., sygn. P 25/06, OTK-A 2007, Nr 2, poz. 9.

Wyrok TK z dnia 21 października 2014 r., sygn. K 38/13, OTK-A 2014, Nr 9, poz. 104.

Wyrok TS UE z dnia 18 marca 2014 r. w spr. C-363/12 Z przeciwko A Government Department

(Dz. Urz. UE C z 2014 r., Nr 142, s. 7). 